\title{
SOVEREIGNTY OVER CERTAIN FRONTIER LAND: BELGIUM/THE NETHERLANDS ${ }^{1}$
}

Arthough both parties had accepted the jurisdiction of the World Court ipso facto and without special agreement under article 36(2) of the Statute, ${ }^{2}$ this case was laid before the Court by special agreement between them, ${ }^{3}$ article I of which is as follows: ${ }^{4}$

The Court is requested to determine whether sovereignty over the plots shown in the survey and known from 1836 to 1843 as Nos. 91 and 92, Section A, Zondereygen, belongs to the Kingdom of Belgium or the Kingdom of the Netherlands.

As the Court remarked, ${ }^{5}$

The frontier between the two States in the area where the two plots in dispute are situated presents certain unusual features. Whilst the frontier in general is a linear one, in the area north of the Belgian town of Turnhout there are a number of enclaves formed by the Belgian commune of BaerleDuc and the Netherlands commune of Baarle-Nassau.

The territory of the Belgian commune of Baerle-Duc is not continuous. It is made up of a series of plots of land, many of which are enclosed in the Netherlands commune of Baarle-Nassau. Various pieces of the commune of Baerle-Duc are not only isolated from the main territory of Belgium but also one from another. Neither is the territory of the commune of BaarleNassau continuous: that commune has enclaves within Belgium. The Court is informed that the origin of this situation is very ancient.

In 1836 , before the separation of Belgium and The Netherlands was sanctioned by the Treaty of London, $1839,^{\circ}$

an attempt was made by the burgomasters of the two communes to establish the exact boundaries between the two communes in order to secure an equitable allocation of land tax. In that year, the burgomasters, with their offcials, proceeded to establish as exactly as possible the division that had existed

\footnotetext{
${ }^{1}$ Case Concerning Sovereignty over Certain Frontier Land (Belgium/The Netherlands), [1959] I.C.J. Rep. 209. See also [1958-59] I.C.J. Y.B. 100.

${ }^{2}$ [1947] id. at 130; [1958-59] id. at 207, 217 .

${ }^{8}$ See Stat. InT's CT. Just. art. 36, para. I.

[ [1959] I.C.J. Rep. at 2 II.

5 Id. at $212-13$. $(1856)$.

${ }^{8}$ [ig59] I.C.J. Rep. at 213. 27 British and Foreign State Papers 990, 1000
} 
from the earliest times between the plots of land enclosed within these communes. They established a Minute which is dated 29 November I836, but which was not completed until about the middle of $\cdot 1839$. It $\cdot$ was finally signed on 22 March $184 \mathrm{I}$.

One copy of this "communal minute" recorded that plots 78-III, obviously inclusive of numbers $9 \mathrm{I}$ and 92 , belonged to Baarle-Nassauthat is, to what was to become Netherlands territory; the other copy apparently was lost.

Under the Treaty of London, a boundary commission was set up and was signed, but did not complete its work until I843. Meanwhile, the two governments signed a boundary treaty ${ }^{7}$-after Belgium rejected a proposal for exchange of territory with a view to settlement and declared in favor of the status quo, which, accordingly, was provided for in the boundary treaty. That treaty also stipulated that the commission should draft a convention "in accordance with the foregoing provisions." The resulting Boundary Convention of August $8,1843,^{\circ}$ provided as follows: ${ }^{10}$

The frontier between the Kingdom of the Netherlands and the Kingdom of Belgium stretches from Prussia to the North Sea.

The descriptive minute, the detailed survey maps and topographical maps, scale I/I0,000, prepared and signed by the Commissioners, shall remain annexed to the present Convention and shall have the same force and effect as though they were inserted in their entirety.

On reaching the said communes of Baerle-Duc and Baarle-Nassau, the boundary is interrupted in consequence of the impossibility of drawing a continuous line between these two communes, in view of the provisions of Article I4 of the Treaty of 5 November I842, which says:

"The status quo shall be maintained both with regard to the villages of Baarle-Nassau (Netherlands) and Baerle-Duc (Belgium) and with regard to the ways crossing them."

The "descriptive minute" referred to contained a provision quoting the preceding paragraph from the Treaty of 1842 . It then purported to transcribe the old "communal minute" understood to have been agreed to in 1836 and signed in $184 \mathrm{I}$. What äctually appears is not simply that plots 78-I I i belong to Baarle-Nassau, but that ${ }^{11}$

3 id at 8 is.

${ }^{8} I d$. at 837. Art. 7o. Translation from the French.

- Ratifications exchanged Oct. 3, 1843 .

${ }^{10}$ Articles 1, 3, and 14(5), [1959] I.C.J. Rep. 214, 215 . Translation from the French.

${ }^{11}$ Id. at 216 . Translation from the French. 
Plots numbers 78 to 90 inclusive belong to the commune of Baarle-Nassau. Plots numbers $9 \mathrm{r}$ and 92 belong to Baerle-Duc.

Plots numbers 93 to I I I inclusive belong to Baarle-Nassau.

An accompanying map, made a part of the Boundary Convention, shows plots 9I-92 as belonging to Belgium.

The Court considered the question whether the Boundary Convention of I 843 determined of itself the ownership of the plots by Belgium or confined its determination to a reference to the status quo. In accepting the former alternative and reaching the conclusion ${ }^{12}$ that Belgian ownership established in 1843 had not been extinguished, the Court made use of the reasoning that follows.

The Court regarded as beyond question the authority of the Boundary Commission, under the treaty of 1839 , to demarcate, and hence to determine, the ownership of the two communes in dispute. This it deemed to be confirmed by the Boundary Convention of 1843 . The express words of these two instruments were held to represent the common intention of the two states. Accordingly: ${ }^{13}$

Any interpretation under which the Boundary Convention is regarded as leaving in suspense and abandoning for a subsequent appreciation of the status quo the determination of the right of one State or the other to the disputed plots would be incompatible with that common intention.

The Court reaches the conclusion that the Boundary Convention was intended to determine, and did determine, as between the two States, to which State the various plots in each commune belonged. Under its terms, the disputed plots were determined to belong to Belgium.

It will be remembered, however, that in the old "communal minute" of r836-4r (which had been placed before the Court by The Netherlands) plots 9I-92, necessarily a part of plots 78-I I r, were by the local authorities of the Belgian and Netherlands communes, conceded to be a part of Baarle-Nassau-that is, of The Netherlands. The Netherlands Government had vigorously contended that, as the relevant treaties indicated that the status quo was to be maintained, plots $9 \mathrm{I}-92$ had been allotted to The Netherlands. It urged that the essential documents upon which the boundary commission based the decision written into the Boundary Convention of $\mathrm{r} 843$ contained an error of transcription which

\footnotetext{
${ }^{12}$ The judges stood 10-4. The Court was composed of President Klaestad; VicePresident Zafrulla Khan; Judges Basdevant, Hackworth, Winiarski, Badawi, ArmandUgon, Kojevnikov, Sir Hersch Lauterpacht, Moreno Quintana, Córdova, Wéllington Koo, Spiropoulos, and Sir Percy Spender.

${ }^{18}$ [1959] I.C.J. Rep. at $221-22$.
} 
vitiated that decision. The Court, however, after examination of all the evidence before it, felt that the explanation thus put forward failed "to have regard to the true function" of the boundary commission and to the facts as they appeared to it:.14

The Commission was not a mere copyist. Its duty was to ascertain what the status quo was. It had authority to fix the limits between the two States, which duty it discharged.

Apparently it was a copy of the communal minute then in the possession of the Netherlands contingent of the Commission, which differed from the text presented by the Netherlands Government in the case at hand, that proved to be decisive. In final support of its finding that no case of mistake had been made out, the Court said:15

The Boundary Convention of 1843 was the result of several years of labour, with members of the Mixed Boundary Commission not only in contact with the respective communal administrations but also with the Governments of the respective States. According to information furnished to the Court, copies of the text of the Communal Minute to be incorporated in the Descriptive Minute, and which was in fact incorporated therein, were signed by the secretaries of each commune. The actual text transcribed was accordingly known to both communes and both States. The Convention was confirmed by the Parliament of each State and ratified in accordance with their constitutional processes. Its terms have been published in each State. For almost a century the Netherlands made no challenge to the attribution of the disputed plots to Belgium.

The Netherlands, however, was able to show various acts and practices which it claimed amounted to an effectual assumption of title by prescription or, in the words of the Court, "in derogation of title established by treaty." Until 192I-22, when considerably increased utilization and settlement of the areas began to occur, and when official correspondence between the two governments of a controversial character began to take place, the question of title was not a subject of any noteworthy interest to either of them. But over against The Netherlands claim, the century-long record was not without instances of assertion of ownership by Belgium. Between 1889 and $\mathrm{r} 892$, for instance, efforts were made by the two states to rectify the frontier and establish a continuous-line boundary. A boundary commission was set up and a convention was signed by the plenipotentiaries of both, but

\footnotetext{
${ }^{14} I d$. at 226 .

${ }^{18}$ Id. at 227 .
} 
never ratified, under the terms of which Belgium agreed to cede to The Netherlands, inter alia, the two plots in dispute in the present case. Remarked the Court: ${ }^{18}$

The unratified Convention of $\mathrm{I} 892$ did not, of course, create any legal rights or obligations, but the terms of the Convention itself and the contemporaneous events show that Belgium at that time was asserting its sovereignty over the two plots, and that the Netherlands knew it was so doing. In a letter of 20 August 1890 , the Belgian Minister for Foreign Affairs had informed the Netherlands Minister in Brussels that an enclave, intersected by the railway from Turnhout to Tilburg, had been omitted from the list of territories to be ceded by Belgium to the Netherlands. This enclave comprised the disputed plots; they were incorporated in the Convention of 1892 and subsequently specifically covered by a separate Declaration of December of that year. The Netherlands did not in 1892 , or at any time thereafter until the dispute arose between the two States in 1922, repudiate the Belgian assertion of sovereignty.

All in all, the Court felt, Belgium's ownership, "established in 1843 ," had "not been extinguished."

Four members of the Court, on the other hand, were of opposite opinion.

Judge Lauterpacht $t^{17}$ felt that the copy of the communal minute submitted by The Netherlands, the authenticity of which was not effectually challenged, should be given greater weight than the later minute which formed the essential provision of the convention of 1843 -which he considered "void and inapplicable on account of uncertainty and unresolved discrepancy." He was impressed with the long-continued line of Netherlands administration of these areas, entirely surrounded as they were by undisputedly Netherlands territory, which, to him, provided "an additional reason why, in the absence of clear provisions of a treaty, there is no necessity to disturb the existing state of affairs and to perpetuate a geographical anomaly."

Judge Spiropoulos ${ }^{18}$ considered the "international legal status of the disputed plots" to be "extremely doubtful." Confronted with two hypotheses as to what really was the status quo at the time of the separation of the two countries, as expressed in the communal minute signed in I84I, he felt that preference ought to be given to the one that seemed "the less speculative"-in his judgment that of The Netherlands.

\footnotetext{
${ }^{16}$ Id. at 229-30.

${ }^{17} I d$. at 230-32.

${ }^{18} I d$. at 232 .
} 
Judge Armand-Ugon ${ }^{19}$ made a minute chronological examination of the documents before the Court upon which the parties to the lawsuit based their claims, and of the facts and circumstances constituting what he called the "effective, notorious and peaceful possession of the plots" after 1843 by The Netherlands. He remarked: ${ }^{20}$

The Communal Minute, which was begun on 29 November 1836 and completed in 1839 , being agreed and signed by the authorities of the two communes on 22 March I84I, occupies a position of cardinal importance in the present case. ...

The separation of Belgium and the Netherlands ... had made it necessary to draw up a minute recording the ownership of the plots making up the two communes of Baarle-Nassau and Baerle-Duc.

The authorities of the two communes and those who drew it up proceeded, in pursuance of instructions received from the respective authorities, to "ascertain as accurately as possible the boundaries which had long existed between the enclaved plots within the communes." This minute was drawn up after discussion on the bases of the Survey Register, the lists of plots, the Property Registers, and the testimony of the oldest inhabitants; all differences of opinion were settled with the assent of the owners. The document was completed in 1839 but signed by the authorities of Baerle-Duc only in March I84I, when the Mixed Boundary Commission had already begun its work. All the precautions indicated reveal the care and seriousness which went into the drafting of this important document, free of erasures or additions, stamped with the seals of the two communes, which was drawn up in two copies recording the official text, and deposited in the archives of each of the two communes. The original copies could not but be identical. The two Minutes follow the forms of a treaty or convention between the two communes. It is a single legal instrument, the work of the authorities of the two communes which it will not be possible to alter save by their agreement. It indicates who are the contracting parties; a preamble states the reasons which have determined its conclusion and the purpose in view, which is to record certain facts. The Minute agreed to by the two communes, which consists of fourteen pages and relates to 5,732 survey plots, constitutes an agreement between the communal authorities of the two States. Only the copy deposited in the archives of the commune of Baarle-Nassau has been put in this case; the other copy, belonging to Baerle-Duc, has not been produced by the Belgian Government. This failure to produce it is to be regretted... .

In the absence of the equally authentic copy which was not before the Court, this copy should have been decisive of the status quo and of the

\footnotetext{
${ }^{10}$ Id. at 233 .

${ }^{30} \mathrm{Id}$. at $234-35$.
} 
case. Moreover, the claim of The Netherlands, based on the "effective, peaceable and public exercise of State functions," should have been given preference over the title relied upon by Belgium, "which has never really exercised the State competence which it regards itself as holding." In support of his position, Judge Armand-Ugon cited previous decisions of the World Court. ${ }^{21}$

Judge Moreno Quintana took positions resembling in general those of Judge Armand-Ugon. He laid emphasis upon the "error . . . so obvious that it is only necessary for the Court to observe its existence" (such observation he thought "inescapable"), which he felt was contained in the descriptive minute that formed the decisive provision in the boundary convention of $\mathrm{r} 843$. He cited numerous decisions by international tribunals. ${ }^{22} \mathrm{He}$ contributes an especially interesting paragraph of history:

The dispute about the plots in question originates from the division of the ancient seigneury of Baarle into two seigneuries, as a consequence of the division, in the thirteenth century, of the holding of the Berthout family. The commune of Baarle-Nassau fell to the family of that name, who were Barons of Breda; later is passed to the United Provinces, which were the forerunners of the present Kingdom of the Netherlands. The commune of Baerle-Duc belonged to the House of Brabant and afterwards to the Southern Netherlands, which were the nucleus of the present Kingdom of Belgium. But as the commune of Baarle-Nassau was rich in heath-lands, which BaerleDuc was without, the inhabitants of the latter commune got into the habit of making use of those which they lacked. Hence arouse a certain network of interests between the two communes.

\footnotetext{
${ }^{21}$ The Fisheries Case, [1951] I.C.J. Rep. I16, 138 ; The Eastern Greenland Case, P.C.I.J., ser. $A / B$, No. 53 , at $62-63$ (1933); Sovereignty over the Minquiers and Ecrehos, [1953] I.C.J. Rep. 47, 67-70.

${ }^{22}$ Island of Palmas, 2 U.N. Rep. Int'l Arb. Awards 829, 852-54 \& 870 (1928); Banks of Grisbadarna, Hague CourT Reports I30-32; Island of Clipperton, 2 U.N. Rep. Int'l Arb. Awards 1r05, Irog-ro (193I); Island of Timor, Hague CoURT REPORTs 362 ; Conditions of Labour in Agriculture, P.C.I.J., ser. B., Nos. 2 \& 3, at 23 (1922); Treatment of Polish Nationals in Danzig, P.C.I.J., ser. A/B, No. 44 , at 33 (1932); Factory at Chorzów (Merits), P.C.I.J., ser. A, No. 7, at 5 I (1926); Reservations to Convention on Genocide, [ 195 1] I.C.J. Rep. 28.
} 